\title{
Cost Optimization of Food Diet for Adult Filipino Patients With Stage 1 or Stage 2 Chronic Kidney Diseases
}

\author{
Rolan J. Malvar ${ }^{\text {, }}$ John Hilton F. Funtilar ${ }^{\text {b }}$, Michelle Jane I. Ibasan ${ }^{\text {, }}$ John Joseph Luis M. Vite ${ }^{\text {d }}$ \\ ${ }^{\text {a }}$ Chief, Extension Management Office, Office of the Vice President for Research, Extension, and Development, Assistant \\ Professor, Department of Mathematics and Statistics, College of Science, Polytechnic University of the Philippines - Sta. \\ Mesa, Manila \\ ${ }_{\text {b,c,d }}$ Polytechnic University of the Philippines - Sta. Mesa, Manila
}

Article History: Received: 10 November 2020; Revised 12 January 2021 Accepted: 27 January 2021; Published online: 5 April 2021

\begin{abstract}
Chronic kidney disease (CKD) is a very common disease in the Philippines. Some of its main causes are hypertension and diabetes. This study is aimed to develop an optimal food dietary model from ninety (90) combinations of linear programming models for adult Filipino patients with Stage 1 or Stage 2 Chronic Kidney Disease. This process will search for the lowest possible cost of their daily food plan while satisfying their daily nutritional requirements. The diet contains six nutritional requirements which are protein, sodium, potassium, phosphorous, calcium and calories. The thirteen cooked food commodities are the following: pork, milkfish, chicken, tilapia, egg, white rice, roasted green beans with garlic, sautéed cabbage, stir-fry bitter gourd, coconut meat, avocado, mango, and oat bran. Using the selected linear programming model which consist of chicken, tilapia, white rice, roasted green beans with garlic, stir-fry bitter gourd, coconut meat, and oat bran, the minimized daily dietary plan cost for adult male is $\mathrm{P} 134.23$, and adult female with $\mathrm{P} 133.2$
\end{abstract}

Keywords: Linear Programming, Chronic Kidney Diseases, Cost Optimization

\section{Introduction}

Kidneys are two bean-shaped organs which serve as the filter of the body. They excrete the waste from our blood, maintain fluid balance in the body, and produce rennin and erythropoietin which helps stimulates the production of red blood cells. When the kidneys are diseased, they become less able to rid the body of waste products of protein metabolism, excess electrolytes and fluid.[1] Chronic Kidney Disease (CKD) includes conditions that damage your kidneys and decrease their ability to keep you healthy. CKD may be caused by Diabetes, High Blood Pressure and other disorders such as Glomerulonephritis. [2] Glomerular filtration rate (GFR) is the number used to figure out a person's stage of kidney disease. The nutritional care of patients with renal disease should be monitored properly. We chose the early Stages of Chronic Kidney Disease, stages 1 and 2, wherein nutritional diet and calculated intake are most needed to control the signs and symptoms, reduce complications, to delay and possibly stop the progression of the disease to lower stages of CKD. [1] Moreover, costs, combinations and availability of foods are focused and analyzed as well to give the patients the least cost possible combinations while maintaining the necessary nutritional information. We used cost minimization which is a financial strategy that aims to achieve the most cost-effective wayof

delivering goods and services to the required level of quality.

Urrutia, Mercado and Tampis developed a linear programming model using the cost minimization method to create the cheapest combination of food commodities that is required for the daily nutritional diet of people who suffer from diabetes. Their study required a 2000-calorie diet for a diabetic person. According to their findings, an adult diabetic male ages 50 and above need to spend a minimum of 72.22 pesos for their daily meal plan. In order toattaintheminimumspending,thefoodsmustconsistof

60.49 grams of anchovy, 91.24 grams of carrot, 121.92 grams of durian, 121.41 grams of chicken egg, 70.82 grams of pork (lean), and 369.70 grams of rice (well-milled). For a 50 year old and above diabetic female, the minimum spending is 64.65 pesos per day and the food must consist of 75.87 grams of anchovy, 43.38 grams of carrot, 160.46 grams of durian, 69.66 grams of chicken egg, 23.16 grams of pork (lean) and 416.19 grams of rice(well-milled).[3]

A study conducted by Briend, André*† et'al (2003), shows that linear programming can be used to analyze and optimize children's diets during the complementary feeding program. They were able to developed a linear programming model whose constraints are nutritional requirements and palatabillity requirements. Their results 
showed that linear programming can be used to easily translate internationally accepted nutritional [4]

recommendations into sound food-based guidelines based on locally available foods and local market prices.

\section{Objectives Of The Study}

The main objective of the study was to make an optimal diet plan for adult patients with stage 1 or stage 2 Chronic Kidney. The study used the cost minimization technique to create an optimal model for diet plan by minimizing the cost per meal of the CKD patients while satisfying their nutrient intake.

\section{Materials And Methods}

The study aims to help adult Filipino patients, both male and female, between ages 20 and 60 with average height and weight ranging from 151.4 centimeters for females and 163.0 centimeters for males weighing 54.3 kilograms for females and 61.3 kilograms for males based from anthropological data for adults. The nutritional diet was consisted of six nutritional requirements which are protein, sodium, potassium, phosphorous, calcium calories along with thirteen food commodities provided with their nutritional references from different food groups which consists of the following: Pork, fresh, separable fat, cooked

; Fish, milkfish, cooked, dry heat; Chicken, broilers or fryers, meat and skin, cooked, roasted; Fish, tilapia, cooked, dry heat; Egg, whole, cooked, scrambled; Rice, white, medium-grain, enriched, cooked; Roasted Green Beans with Fresh Garlic cooked with Green beans; Olive oil and Garlic; Sautéed Cabbage cooked with Cabbage, Olive oil and Honey; Stir-fry Bitter Gourd cooked with Bitter Gourd, Olive oil, Garlic, and Onions; Coconut meat, raw; Philippine Avocado; Philippine Mango; and Oat bran, cooked. Meats and vegetables are cooked with Olive Oil to maintain the necessary calorie intake while providing a low-protein diet for thepatient.

The researchers use updated sources for the prices and nutritional value of the commodities which includes: Philippine Statistical Association's (PSA), Department of Trade and Industry's (DTI), Robinson's Supermarket's online database, Philippine Statistical Association (PSA), Department of Trade and Industry (DTI), Information from Food and Nutrition Research Institute's (FNRI), Management of Renal Diseases' Handbook and National Kidney Foundation Kidney Disease Outcomes Quality Initiative (NKF-KDOQI)'s, Clinical Practice Guidelines for Chronic Kidney Disease: Evaluation, Classification, and Stratification, provided the necessary values of nutritional intake for Filipino adult patients. United States Department of Agriculture's (USDA), Food and Nutrition Research Institute. Department of Science and Technology (FNRI- DOST)'s $2^{\text {nd }}$ National Nutritional Summit: $8^{\text {th }}$ National Nutritional Survey.

A linear programming is a method to accomplish the best outcome from the situation designed in a mathematical

model which is represented by linear relationships. Therefore, the solution to a linear programming problem is the set of variables which gives an optimal value to the objective function and at the same time does not violate the constraints imposed upon the variables. The simplex method, invented by George Dantzig in 1947, is an approach for determining the optimal value of a linear program. The method produces an optimal solution to satisfy the given constraints and produce a maximum objective value.[5] To use the Simplex Method, the given linear programming model needs to be in standard form, where slack variables can be introduced. Using the tableau and pivot variables, an optimal solution can be reached. MATLAB is a high-performance language for technical computing. It integrates computation, visualization, and programming in an easy-to-use environment where problems and solutions are expressed in familiar mathematical notation. Furthermore, it is used for signal processing and communications, image and video processing, control systems, test and measurement, developing and running algorithms, creating user interface (UI) and visualization. These factors make MATLAB an excellent tool for teaching and research.

\subsection{Objective Function and Decision Variables}

Table 1. Average Price per serving of basic commodities

\begin{tabular}{|l|l|c|}
\hline Variable & Commodities & $\begin{array}{c}\text { Price } \\
\mathbf{1 0 0 g}\end{array}$ \\
\hline$x 1$ & $\begin{array}{l}\text { Pork, fresh, separable fat, } \\
\text { cooked }\end{array}$ & P35.58 \\
\hline$x 2$ & Fish, milkfish, cooked, dry & P30.47 \\
\hline
\end{tabular}




\begin{tabular}{|c|c|c|}
\hline & heat & \\
\hline$x 3$ & $\begin{array}{l}\text { Chicken, meat and skin, } \\
\text { cooked, roasted }\end{array}$ & Р29.01 \\
\hline$x 4$ & $\begin{array}{l}\text { Fish, tilapia, cooked, dry } \\
\text { heat }\end{array}$ & Р25.61 \\
\hline$x 5$ & $\begin{array}{l}\text { Egg, whole, cooked, } \\
\text { scrambled }\end{array}$ & Р25.93 \\
\hline$x 6$ & $\begin{array}{l}\text { Rice, white, medium- } \\
\text { grain, } \\
\text { cooked }\end{array}$ & P1.45 \\
\hline$x 7$ & $\begin{array}{l}\text { Roasted Green Beans with } \\
\text { Fresh Garlic }\end{array}$ & Р23.77 \\
\hline$x 8$ & Sautéed Cabbage & Р38.63 \\
\hline$x 9$ & Stir-fry Bitter Gourd & Р24.09 \\
\hline$x 10$ & Coconut meat, raw & P10.08 \\
\hline$x 11$ & $\begin{array}{l}\text { Philippine Avocado (per } \\
\text { kilo) }\end{array}$ & P32.00 \\
\hline$x 12$ & $\begin{array}{l}\text { Philippine Mango (per } \\
\text { kilo) }\end{array}$ & P14.33 \\
\hline$x 13$ & Oat bran, cooked & P24.20 \\
\hline
\end{tabular}

Source: Philippines Statistics Authority (September 2018 to November 2018)

Table 1 shows the average daily price per 100 grams of servings of each decision variables. It can be seen in this table that sautéed cabbage has the highest price ofPhp

38.63 pesos per servings while rice has the lowest price of Php 1.45 per servings. These variables were considered because of their availability in the market and can provide the necessary nutritional daily requirements of patientswith

stage 1 or stage 2 chronic kidney diseases. These information was used to developed the objective function of themodel.

\subsection{Constraints of the Model}

Table 2. Nutritional Requirements andtheir RestrictiveValues

\begin{tabular}{|c|l|l|}
\hline $\begin{array}{c}\text { Nutritional } \\
\text { Requirements }\end{array}$ & Female & Male \\
\hline Protein & 40.725 & $45.975 \mathrm{~g} / \mathrm{kg}$ \\
\hline Sodium $(\mathrm{Na})$ & $\leq 2.3$ & $\leq 2.3$ \\
\hline Potassium $(\mathrm{K})$ & $\leq 2.37$ & $\leq 2.37$ \\
\hline Calcium $(\mathrm{Ca})$ & $\leq 2.00 \mathrm{~g}$ & $\leq 2.00 \mathrm{~g}$ \\
\hline Phosphorous & $0.70-1.00 \mathrm{~g}$ & $0.70-1.00 \mathrm{~g}$ \\
\hline P) & & $2145.5 \mathrm{kcal} / \mathrm{g}$ \\
\hline Calories $(\mathrm{cal} / \mathrm{g})$ & 1900.5 & $\mathrm{patienth}$ \\
\hline
\end{tabular}

Table 2 shows the nutritional requirements of the stage 1 or 2 CKD patients that were given by National Kidney Foundation Kidney Disease Outcomes Quality Initiative (NKF KDOQI), and Clinical Practice Guidelines for Chronic Kidney Disease: Evaluation, Classification and Stratification. [5] It shows that nutritional requirements of 
male CKD patients were different from the female patients in terms of protein and caloriesintake.

Table 3: Restrictive values for Each Decision Variables

\begin{tabular}{|c|c|}
\hline $\begin{array}{c}\text { Food } \\
\text { Variables }\end{array}$ & $\begin{array}{c}\text { Restrictive } \\
\text { Values }\end{array}$ \\
\hline$x 5$ & $\geq 0.50$ \\
\hline$x 6$ & $\leq 2.00$ \\
\hline$x 7, x 8, x 9$ & $\geq 1.00$ \\
\hline $\begin{array}{c}x 10, \\
x 12, x 13\end{array}$ & $\geq 1.00$ \\
\hline
\end{tabular}

Table 3 shows the restrictive values of each decision variables. These restrictions were made to ensure the palatability and reject unrealistic diets.

Table 4: Nutritional Facts per Gram of each food products

\begin{tabular}{|l|l|l|l|l|l|l|}
\hline Variables & $\begin{array}{l}\text { Protei } \\
\mathrm{n}\end{array}$ & $\mathrm{Na}$ & $\mathrm{K}$ & $\mathrm{Ca}$ & $\mathrm{P}$ & $\mathrm{Cal}$ \\
\hline$x 1$ & $5.15 \mathrm{~g}$ & 0.042 & 0.091 & 0.016 & 0.08 & 695.00 \\
\hline$x 2$ & 19.21 & 0.068 & 0.273 & 0.047 & 0.152 & 377.00 \\
\hline$x 3$ & 27.30 & 0.082 & 0.223 & 0.015 & 0.182 & 239.00 \\
\hline$x 4$ & 19.09 & 0.042 & 0.277 & 0.01 & 0.149 & 331.00 \\
\hline$x 5$ & 7.29 & 0.107 & 0.096 & 0.048 & 0.12 & 347.00 \\
\hline$x 6$ & 2.380 & 0.000 & 0.029 & 0.003 & 0.037 & 130.00 \\
\hline$x 7$ & 1.51 & 0.003 & 0.114 & 0.036 & 0.025 & 266.00 \\
\hline$x 8$ & 0.63 & 0.008 & 0.056 & 0.016 & 0.011 & 308.00 \\
\hline$x 9$ & 0.8 & 0.006 & 0.218 & 0.012 & 0.03 & 257.00 \\
\hline$x 10$ & 3.33 & 0.02 & 0.356 & 0.014 & 0.113 & 354.00 \\
\hline$x 11$ & 2 & 0.008 & 0.484 & 0.013 & 0.05 & 160.00 \\
\hline$x 12$ & 2.500 & 0.150 & 0.238 & 0.000 & 0.05 & 325.00 \\
\hline$x 13$ & 3.21 & 0.001 & 0.092 & 0.01 & 0.119 & 40.000 \\
\hline
\end{tabular}

Table 4 shows that nutritional content of each decision variables based on the United States Department of Agriculture's (USDA) and Food and Nutrition Research Institute. Department of Science and Technology(FNRI-

DOST)'s $2^{\text {nd }}$ National Nutritional Summit: $8^{\text {th }}$ National Nutritional Survey.

\section{Results And Discussion}

Based on gathered data fromdifferent national and international government agencies the following linear programming model were developed on male and female stage 1 or 2 CKDpatients.

Linear Programming Model and Optimal Solution for Food Cost Optimization of stage 1 or 2 CKD Female Patients

Minimize Cost $=29.013 \mathrm{X} 3+25.607 \mathrm{X} 4+1.450 \mathrm{X} 6+23.773 \mathrm{X} 7+24.087 \mathrm{X} 9+10.076 \mathrm{X} 10+24.2 \mathrm{X} 13$

\section{Subject to:}

Necessary amount of Protein per 100 grams $40.725=19.21 \mathrm{X}_{3}+19.09 \mathrm{X} 4+2.3800 \mathrm{X} 6+1.51 \mathrm{X} 7+$

$0.800 \times 9+3.330 \mathrm{X}_{10}+3.21 \mathrm{X}_{13}$

Necessary amount of Sodium per 100 grams

$0.068 \mathrm{X} 3+0.042 \mathrm{X} 4+0.0000 \mathrm{X} 6+0.003 \mathrm{X} 7+0.006 \mathrm{X} 9+$

$0.020 \times 10+0.001 \times 13 \leq 2.30$

Necessary amount of Potassium per 100 grams

$0.273 \mathrm{X} 3+0.277 \mathrm{X} 4+0.0290 \mathrm{X} 6+0.114 \mathrm{X} 7+0.218 \mathrm{X} 9+$ 
$0.356 \times 10+0.092 \times 13 \leq 2.37$

Necessary amount of Calcium per 100 grams

$0.047 \times 3+0.01 \times 4+0.0030 \times 6+0.036 \times 7+0.012 \times 9+$

$0.014 \mathrm{X} 10+0.01 \mathrm{X} 13 \leq 2.00$

Necessary amount of Phosphorous per 100 grams $0.70 \leq 0.152 \mathrm{X} 3+0.149 \mathrm{X} 4+0.0370 \mathrm{X} 6+0.025 \mathrm{X} 7+0.030 \mathrm{X} 9$ $+0.113 \times 10+0.119 \times 13 \leq 1.00$

Necessary amount of Calories per 100 grams 1900.5=377.000X $3+331 \mathrm{X} 4+130.000 \mathrm{X} 6+266.000 \mathrm{X} 7+$ $257.000 \times 9+354.000 \times 10+40 \times 13$

\subsection{Optimal Solutions:}

Table 5: Optimal solution for Adult Female Patients with stage 1 or 2 Chronic Kidney Disease

\begin{tabular}{|l|l|l|l|l|l|l|l|}
\hline Var & Protein & Na & K & Ca & P & Cal & $\begin{array}{l}\text { Optimal } \\
\text { solution }\end{array}$ \\
\hline $\mathrm{x} 3$ & 27.300 & 0.082 & 0.223 & 0.015 & 0.182 & 239.000 & 0.50 \\
\hline $\mathrm{x} 4$ & 19.09 & 0.042 & 0.277 & 0.01 & 0.149 & 331 & 0.50 \\
\hline $\mathrm{x} 6$ & 2.3800 & 0.0000 & 0.0290 & 0.0030 & 0.0370 & 130.0000 & 1.14 \\
\hline $\mathrm{x} 7$ & 1.510 & 0.003 & 0.114 & 0.036 & 0.025 & 266.000 & 1 \\
\hline $\mathrm{x} 9$ & 0.800 & 0.006 & 0.218 & 0.012 & 0.030 & 257.000 & 1 \\
\hline $\mathrm{x} 10$ & 3.330 & 0.020 & 0.356 & 0.014 & 0.113 & 354.000 & 2.52 \\
\hline $\mathrm{x} 13$ & 3.21 & 0.001 & 0.092 & 0.01 & 0.119 & 40 & 1.28 \\
\hline
\end{tabular}

Table 5 shows the optimal solution of the linear programming model of adult female patients with stage 1 and 2 CKD disease. It shows that adult female patients with

CKD should consume 50 grams (0.5 servings) of chicken and fish tilapia, 114 grams (1.14 servings) of rice, 100 grams (1 serving) of green beans and bitter gourd, 252 grams (2.52 servings) of coconut meat and 128 grams (1.28 servings) of Oat Bran to satisfy their daily nutritional requirements. The combination of these foods gave the minimum daily cost of Php 133.20.

\subsection{Sensitivity Analysis}

Table 6. Optimality Range for Female Dietary Menu

\begin{tabular}{|c|l|l|l|l|l|}
\hline Var & $\begin{array}{l}\text { Final } \\
\text { Value }\end{array}$ & $\begin{array}{l}\text { Reduced } \\
\text { Cost }\end{array}$ & $\begin{array}{l}\text { Obj. } \\
\text { Coeff. }\end{array}$ & $\begin{array}{l}\text { Lower } \\
\text { Bound }\end{array}$ & $\begin{array}{l}\text { Upper } \\
\text { Bound }\end{array}$ \\
\hline$x 3$ & 0.50 & 21.44 & 29.01 & 7.58 & $\infty$ \\
\hline$x 4$ & 0.50 & 21.56 & 25.61 & 4.05 & $\infty$ \\
\hline$x 6$ & 1.14 & 0 & 1.45 & -153.49 & 2.68 \\
\hline$x 7$ & 1 & 29.81 & 23.77 & -6.04 & $\infty$ \\
\hline$x 9$ & 1 & 27.84 & 24.09 & -3.75 & $\infty$ \\
\hline$x 10$ & 2.52 & 0 & 10.08 & 6.45 & 42.90 \\
\hline$x 13$ & 1.28 & 0 & 24.2 & -4.37 & 36.58 \\
\hline
\end{tabular}

Table 6 shows the optimality range of the Female dietary food intake. Its shows that the current solution will remain optimal if the changes in the prices of chicken, Fish Tilapia, Rice, Green Beans, Bitter Gourd, Coconut meat, and oat bran will be within the interval $(7.58, \infty) .(4.05, \infty),(-153.49,2.68),(-6.04, \infty),(-3.75, \infty),(6.45$, 42.90) and(-

$4.37,36.58)$ respectively.

$$
\begin{aligned}
& \text { 4.3.LinearProgramming } \\
& \text { Model for Food Cost Optimization of stage } 1 \text { or } 2 \text { CKD MalePatients } \\
& \text { Minimize Cost }=29.013 X 3+25.607 X 4+1.450 X 6+23.773 X 7+24.087 X 9+10.076 X 10+24.2 X 13 \\
& 2145.5=239.000 \times 3+331 \times 4+130.000 \times 6+266.000 \times 7+
\end{aligned}
$$


$257.000 \times 9+354.000 \times 10+40 X_{13}$

Optimal Solutions:

Table 7: Optimal solution for Adult Male Patients with stage 1 or 2 Chronic Kidney Disease

\begin{tabular}{|l|l|l|l|l|l|l|l|}
\hline Var & Protein & Na & K & Ca & P & Cal & $\begin{array}{l}\text { Optimal } \\
\text { solution }\end{array}$ \\
\hline x3 & 27.30 & 0.082 & 0.223 & 0.015 & 0.182 & 239.00 & 0.61 \\
\hline x4 & 19.09 & 0.042 & 0.277 & 0.01 & 0.149 & 331 & 0.50 \\
\hline x6 & 2.38 & 0.00 & 0.029 & 0.003 & 0.037 & 130.00 & 2 \\
\hline x7 & 1.51 & 0.003 & 0.114 & 0.036 & 0.025 & 266.00 & 1 \\
\hline x9 & 0.80 & 0.006 & 0.218 & 0.012 & 0.030 & 257.00 & 1 \\
\hline x10 & 3.33 & 0.020 & 0.356 & 0.014 & 0.113 & 354.00 & 2.86 \\
\hline x13 & 3.21 & 0.001 & 0.092 & 0.01 & 0.119 & 40 & 1 \\
\hline
\end{tabular}

Table 7 shows the optimal solution of the linear programming model of adult male patients with stage 1 and 2 CKD disease. It shows that adult male patients with CKD should consume 61 grams ( 0.61 servings $)$ of chicken, 50 grams fish tilapia, 200 grams (2 servings) of rice, 100 grams (1 serving) of green beans and bitter gourd, 286 grams (2.86 servings) of coconut meat and 100 grams (1 serving) of Oat Bran to satisfy their daily nutritional requirements. The combination of these foods gave the minimum daily cost of Php134.23.

\subsection{Sensitivity Analysis}

Table 8. Optimality Male for Female Dietary Menu

\begin{tabular}{|c|c|c|c|c|c|}
\hline Var & $\begin{array}{c}\text { Final } \\
\text { Value }\end{array}$ & $\begin{array}{c}\text { Reduced } \\
\text { Cost }\end{array}$ & $\begin{array}{c}\text { Obj. } \\
\text { Coeff. }\end{array}$ & $\begin{array}{c}\text { Lower } \\
\text { Bound }\end{array}$ & $\begin{array}{c}\text { Upper } \\
\text { Bound }\end{array}$ \\
\hline$x_{3}$ & 0.68 & 0 & 29.01 & 25.84 & 99.94 \\
\hline$x_{4}$ & 0.50 & 2.02 & 25.61 & 23.59 & $\infty$ \\
\hline$x_{6}$ & 2 & -3.27 & 1.45 & $-\infty$ & 4.73 \\
\hline$x_{7}$ & 1 & 17.08 & 23.77 & 6.69 & $\infty$ \\
\hline$x_{9}$ & 1 & 18.21 & 24.09 & 5.88 & $\infty$ \\
\hline$x_{10}$ & 2.86 & 0 & 10.08 & 0.33 & 14.09 \\
\hline$x_{13}$ & 1 & 20.55 & 24.2 & 3.65 & $\infty$ \\
\hline
\end{tabular}

\section{Subject to:}

Necessary amount of Protein per 100 grams

$45.975=27.300 \times 3$

$+19.09 \mathrm{X} 4$

$+2.3800 \times 6$

$+1.51 \times 7+$

$0.800 \times 9+3.330 \times 10+3.21 \times 13$

Necessary amount of Sodium per 100 grams

$0.082 \mathrm{X} 3+0.042 \mathrm{X} 4+0.0000 \mathrm{X} 6+0.003 \mathrm{X} 7+0.006 \mathrm{X} 9+$

$0.020 \mathrm{X} 10+0.001 \mathrm{X} 13 \leq 2.30$

Necessary amount of Potassium per 100 grams

$0.223 \mathrm{X} 3+0.277 \mathrm{X} 4+0.0290 \mathrm{X} 6+0.114 \mathrm{X} 7+0.218 \mathrm{X} 9+$

$0.356 \mathrm{X} 10+0.092 \mathrm{X} 13 \leq 2.37$

Necessary amount of Calcium per 100 grams

$0.015 \mathrm{X} 3+0.01 \mathrm{X} 4+0.0030 \mathrm{X} 6+0.036 \mathrm{X} 7+0.012 \mathrm{X} 9+$

$0.014 \mathrm{X} 10+0.01 \mathrm{X} 13 \leq 2.00$ 
Necessary amount of Phosphorous per 100 grams $0.70 \leq 0.182 \mathrm{X} 3+0.149 \mathrm{X} 4+0.0370 \mathrm{X} 6+0.025 \mathrm{X} 7+0.030 \mathrm{X} 9$

$+0.113 \mathrm{X} 10+0.119 \mathrm{X} 13 \leq 1.00$

Necessary amount of Calories per 100 grams

Table 8 shows the optimality range of the male dietary food intake. Its shows that the current solution will remain optimal if the changes in the prices of chicken, Fish Tilapia, Rice, Green Beans, Bitter Gourd, Coconut meat, and oat bran will be within the interval $(25.84,99.94) .(23.59, \infty),-\infty, 4.73),(6.69, \infty),(5.88, \infty),(0.33$, 14.09) and

$(3.65, \infty)$ respectively.

\section{Conclusion}

Linear Programming have become a powerful tool designing an optimized food diet for Filipino Adult male and female with stage 1 or 3 chronic kidney diseases. It provides an efficient combination of locally found food in the Philippines that minimizes their daily cost while satisfying their daily nutritional requirements, which is more efficient than the empherical "trial and error approach" of most patients with CKD stage 1 or 2. Nutritionist and dieticians should adopt this method for a more economical approach of formulating diet plans not only for those persons with CKD but those people with other illness that requires routinediet.

\section{References}

DAVITA INC., Stages of Chronic Kidney Disease URL: https://www.davita.com/kidneydisease/overview/stages-of-kidney-disease

NATIONAL KIDNEY FOUNDATION, About Chronic Kidney Disease URL:https://www.kidney.org/atoz/content/about- chronic-kidney-disease, February 15, 2017

J.D Urrutia et'al, Minimization of Food Cost on 2000-Calorie Diabetic Diet; Journal of Physics Conference Series; Conf. Ser. 820 012002, IOP Publishing

Briend, André*ł, et'al, Linear Programming: A Mathematical Tool for Analyzing and Optimizing Children's Diets During the Complementary Feeding Period, Journal of Pediatric Gastroenterology and Nutrition, January 2003 - Volume 36 - Issue 1 - p 12-22.

Taha, Hamdy, Operations Research, 8th Edition, Person Prentice Hall, Upper Saddle River, New Jersey. ISBN: 0-13-188923-0

National Kidney Foundation Kidney Disease Outcomes Quality Initiative (NKFKDOQI), Clinical Practice Guidelines for Chronic Kidney Disease: Evaluation, Classification, and Stratification, 2002 Feb;39 (2 Suppl 1):S1-266. pp 146. 